\title{
Pituitary 'pseudotumor': an under-recognised complication of undertreated primary hypothyroidism
}

\author{
Noura Nachawi, ${ }^{1}$ Timothy W Bodnar ${ }^{2}$
}

'Internal Medicine Department, St Joseph Mercy Hospital Ann Arbor, Ann Arbor, Michigan, USA ${ }^{2}$ Endocrinology Department, Ann Arbor Endocrinology and Diabetes, P.C., Ypsilanti, Michigan, USA

\section{Correspondence to} Dr Noura Nachawi, noura.nachawi@stjoeshealth. org

Accepted 25 May 2018
Check for updates

To cite: Nachawi $\mathrm{N}$ Bodnar TW. BMJ Case Rep Published Online First: [please include Day Month Year]. doi:10.1136/bcr-2018 225472

\section{DESCRIPTION}

A woman in her 30s with medical history notable for hypothyroidism due to Hashimoto's thyroiditis had a brain MRI ordered by her neurologist due to change in chronic headache pattern. This had an incidental finding of enlarged pituitary gland. She was referred at that time to an endocrinologist but was not seen. Eighteen months later, she presented with worsening headaches, blurry vision, weight gain and galactorrhoea. Repeat brain MRI showed a $9 \times 10 \times 13 \mathrm{~mm}$ sellar mass extending superiorly, with mass effect on optic chiasm (figure 1A). Thyroid-stimulating hormone (TSH) was 185 $\mathrm{mIU} / \mathrm{mL}$ with low free T3, low free T4, normal prolactin, normal FSH and normal LH. She was then referred to a neurosurgeon and an ophthalmologist. Visual field testing initially showed mild constriction of bilateral visual fields. The neurosurgeon referred her to an endocrinologist for preoperative hormonal evaluation, but the operation date was advanced when subjective visual symptoms were worsening and when repeat visual field testing showed progression over 3 weeks to severe constriction of bilateral visual fields. She did not see an endocrinologist prior to having trans-sphenoidal partial hypophysectomy.

Endocrinology was consulted postoperatively for polyuria, with urine output $>10 \mathrm{~L} /$ day. Laboratory testing revealed central diabetes insipidus and central/secondary adrenal insufficiency for which she is being treated with desmopressin and hydrocortisone. Initial surgical pathology report was 'pituitary adenoma', but after request for further testing and staining, the pathological diagnosis was changed to thyrotrope hyperplasia, with staining showing a diffuse population of TSH-producing cells (figure 1B). When discussing increasing levothyroxine dose with the patient, she told Endocrinology that she had a history of years of very elevated TSH because she felt more suicidal when her levothyroxine dose was increased. After discussion with her treating psychiatrist and additional medication safety measures implemented, levothyroxine dose was slowly titrated. Within 4 months of cautious dose escalation, TSH had normalised. The patient is now being treated for presumptive central/secondary hypothyroidism with future monitoring planned using free T4 levels.

Physiological pituitary hyperplasia due to untreated or undertreated hypothyroidism has been well documented, with characteristic appearance on MRI, and correlation with degree of TSH elevation. ${ }^{12}$ Regression of pituitary enlargement

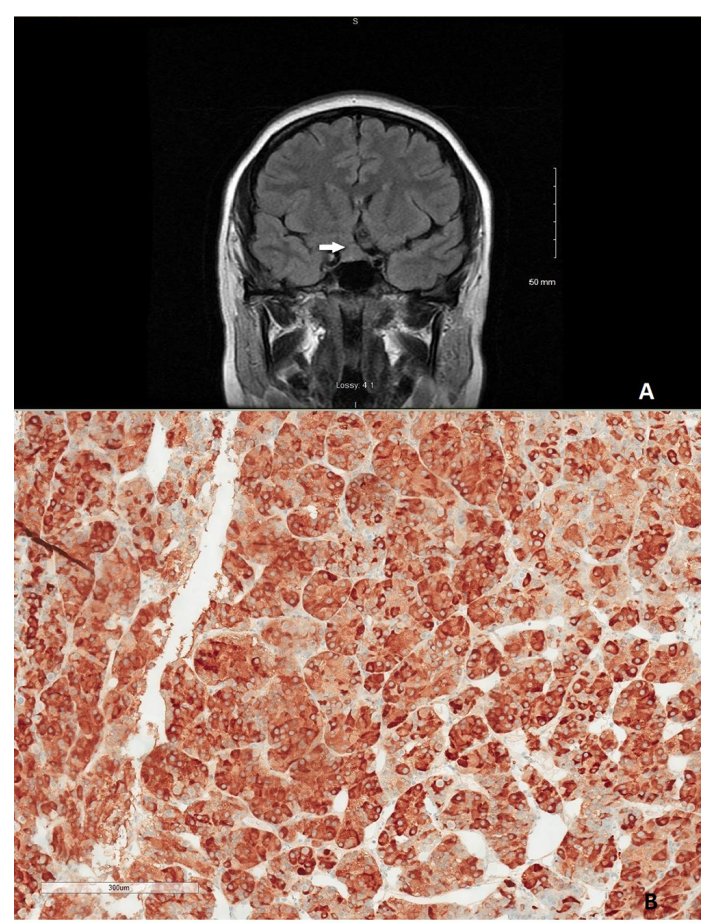

Figure 1 (A) Coronal section of brain MRI. Arrow points to a $9 \times 10 \times 13 \mathrm{~mm}$ sellar mass extending superiorly, with mass effect on optic chiasm. (B) Histology of thyrotrophic pituitary hyperplasia with monomorphic cells stained in brown for thyroid-stimulating hormone expression.

can be seen in a matter of weeks, so usual recommendations are to avoid pituitary surgery. ${ }^{3}$

In our patient's case, worsening visual symptoms and progression of visual field defects prompted neurosurgical intervention before endocrinology evaluation and treatment. Unfortunately, the operation resulted in hypopituitarism with secondary adrenal insufficiency and diabetes insipidus.

\section{Learning points}

- Physiological hyperplasia of the pituitary should be considered in the differential diagnosis of sellar masses and should be considered as a potential consequence of prolonged untreated or undertreated hypothyroidism.

- Appropriate treatment with thyroid hormone should lead to regression of hyperplasia and may help avoid both pituitary surgery and surgical complications such as hypopituitarism and diabetes insipidus. 
Acknowledgements The authors would like to thank John Schaldenbrand, MD, for producing and interpreting the microscopy picture.

Contributors Study conception and design: NN and TWB. Data collection: NN and TWB. Data analysis and interpretation: NN and TWB. Drafting the article: NN and TWB. Critical revision of the article: TWB and NN. Final approval of the version to be published: NN and TWB.

Funding The authors have not declared a specific grant for this research from any funding agency in the public, commercial or not-for-profit sectors

Competing interests None declared.

Patient consent Obtained.

Provenance and peer review Not commissioned; externally peer reviewed. (c) BMJ Publishing Group Ltd (unless otherwise stated in the text of the article) 2018. All rights reserved. No commercial use is permitted unless otherwise expressly granted.

\section{REFERENCES}

1 Joshi AS, Woolf PD. Pituitary hyperplasia secondary to primary hypothyroidism: a case report and review of the literature. Pituitary 2005;8:99-103.

2 Khawaja NM, Taher BM, Barham ME, et al. Pituitary enlargement in patients with primary hypothyroidism. Endocr Pract 2006;12:29-34.

3 De Sousa SM, Earls P, McCormack Al. Pituitary hyperplasia: case series and literature review of an under-recognised and heterogeneous condition. Endocrinol Diabetes Metab Case Rep 2015;2015:1-7.

Copyright 2018 BMJ Publishing Group. All rights reserved. For permission to reuse any of this content visit http://group.bmj.com/group/rights-licensing/permissions.

BMJ Case Report Fellows may re-use this article for personal use and teaching without any further permission.

Become a Fellow of BMJ Case Reports today and you can:

- Submit as many cases as you like

- Enjoy fast sympathetic peer review and rapid publication of accepted articles

- Access all the published articles

- Re-use any of the published material for personal use and teaching without further permission

For information on Institutional Fellowships contact consortiasales@bmjgroup.com

Visit casereports.bmj.com for more articles like this and to become a Fellow 